\title{
Richardia Robineau-Desvoidy (Diptera, Tephritoidea, Richardiidae) from Central Amazon, Brazil
}

\author{
Letícia Barros de Alencar ${ }^{1}$, Lisiane Dilli Wendt ${ }^{1,2} \&$ Rosaly Ale-Rocha ${ }^{1,3}$
}

\author{
${ }^{1}$ Coordenação de Pesquisas em Biodiversidade, Instituto Nacional de Pesquisas da Amazônia (INPA), Av. André Araújo, 2936, Petrópolis, \\ 69011-970 Manaus-AM, Brazil. tycya4@hotmail.com \\ 2Felowship CAPES/FAPEAM; lisidilli@yahoo.com.br \\ ${ }^{3}$ Fellowship PQ/CNPq; alerocha@inpa.gov.br
}

\begin{abstract}
Richardia Robineau-Desvoidy (Diptera, Tephritoidea, Richardiidae) from Central Amazon, Brazil. There are 11 species of Richardia known to Brazil. Of these, only four are known to occur in the Brazilian Amazon Region, where the diversity of Richardia is underestimated. Herein we describe and illustrate Richardia intemperata sp. nov. and Richardia parispina sp. nov. from Amazonas, Brazil. An illustrated key to males from this region is also provided.
\end{abstract}

KEYWORDS. Insecta; Neotropical Region; Richardiinae; taxonomy.

Richardiidae is a relatively small family of flies, with about 180 species in 33 genera (Hancock 2010). It is currently divided into two subfamilies: Epiplateinae and Richardiinae (Steyskal 1987). The distribution of the family is mostly Neotropical, though there are no records to Chile and Patagonia (Aczél 1950). However, a few species occur in the Nearctic Region (Steyskal 1987).

Richardiinae is conspicuously more diverse than Epiplateinae, including more than $90 \%$ of the species in the family (Steyskal 1968). Despite the considerable morphological differences among Richardiinae genera, a preliminary phylogenetic analysis (Wendt \& Ale-Rocha, unpublished data) supports the hypothesis that the subfamily forms a clade. The group has been relatively neglected by taxonomists in the past 40 years, but interest in the taxonomy of Richardiinae has been recently revived: new taxa have been described (Perez-Gelabert \& Thompson 2006; Carvalho et al. 2011; Wendt \& Smit unpublished data; Wendt \& Ale-Rocha unpublished data); generic revisions have been prepared (Wendt \& Ale-Rocha 2012; and unpublished data) and key to all genera was published (Hancock 2010).

Altogether, 60 species of Richardiidae, distributed in 13 genera, are recorded from Brazil. Of these, only 14 species in 9 genera are known to occur in the Brazilian Amazon (Aczél 1950; Steyskal 1968). Considering that the last contribution describing new species of Richardiidae from Brazil dates back to the 1930s (Hennig 1938), and that the regional fauna of these flies has never been studied in depth, these numbers are most likely an underestimation of the real diversity of the group in the country, and in the Amazon.

Richardia Robineau-Desvoidy is the most diverse genus of Richardiidae, with 27 valid species and two subspecies (Aczél 1950; Steyskal 1968) distributed from Mexico to southern Brazil (Steyskal 1968). Up to date, only 11 species have been recorded from the country, four of which occur in the Brazilian Amazon (Steyskal 1968). Richardia is one of the few Richardiidae genera (besides Batrachophthalmum Hendel and Megalothoraca Hendel) with sexually dimorphic species. Some modified structures, for instance stalked eyes (in R. stylops Hennig and R. telescopica Gerstaecker), genal cuticular projections on the head (in R. infestans (Enderlein) and six species from Central America) (Wendt \& Ale-Rocha unpublished data), or strong spines and/or tubercles on the hind femur (e.g. in R. calcarata Hendel; R. pectinata Hendel and $R$. tuberculata Hendel) are present exclusively in males. These structures are very important taxonomic attributes that help in species identification. By contrast, the females of different species are morphologically very similar and are most often difficult to associate with their male counterparts. No complete revision and updated keys to species are available in the literature, and the current number of species of Richardia is far from representing the real diversity of the group. However, the lack of taxonomic contributions on the genus renders the identification of species very difficult, and for this reason, an extensive revision of Richardia is ongoing (Wendt \& Ale-Rocha, unpublished data).

During the course of a study of the Richardiidae from Central Amazon, in Brazil, two species of Richardia with modified spines and cuticular projection on the hind femur were found. These structures are unique in Richardia and are sufficient to distinguish them from all known species of the genus. In this contribution we describe and illustrate those two species. In order to facilitate the identification of the species that occur in the Central Amazon, we provide a key to the males of the species that have been recorded there. As far as we know, they are endemic to that biome. A key to all species of Richardia is forthcoming (Wendt \& Ale-Rocha, unpublished data). 


\section{MATERIAL AND METHODS}

The Central Amazon spans from the north and west of the state of Pará to the Madeira River Valley in the state of Amazonas (Ministério da Integração Nacional, Ministério do Meio Ambiente 2004). The species included in this study were collected in this region, in a reserve of continuous forest at km 41 (area 1501, Esteio farm) (2²6’56"S; 5946’12" W) of the Biological Dynamics of Forest Fragments Project (Projeto Dinâmica Biológica de Fragmentos Florestais PDBFF) of the National Institute for Research in the Amazon (Instituto Nacional de Pesquisas da Amazônia - INPA)/ Smithsonian Institution, situated $80 \mathrm{~km}$ north of Manaus, Amazonas, Brazil. Additional specimens from an area near the PDBFF were also studied.

The material examined belongs to the following institutions: INPA - Instituto Nacional de Pesquisas da Amazônia, Manaus, Amazonas, Brazil; BMNH - Natural History Museum, London, England; ZMHB - Museum für Naturkunde, Berlin, Germany.

All species recorded from the Brazilian Amazon, according to the available literature (e.g. Hendel 1911a, b, 1912; Steyskal 1968), were included in the identification key. Of these, we studied photos of the type-material of Richardia calcarata Hendel and $R$. pectinata Hendel, deposited at the BMNH, and the type of $R$. telescopica Gerstaecker from the ZMHB.

The terminology for the external morphological characters follows Cumming \& Wood (2009), except the terminalia, which follows White et al. (1999).

For label data of type material, individual lines are separated with a forward slash (/), and individual labels are separated with quotes ("'). Information within square brackets ([]) indicates additional data that are not present on the specimen labels.

\section{Richardia Robineau-Desvoidy}

(Figs. 1-22)

Richardia Robineau-Desvoidy, 1830: 728. Type-species, R. saltatoria Robineau-Desvoidy (by monotypy). According to Steyskal (1968), there is considerable uncertainty concerning the identity of Richardia saltatoria. Even though it might be a synonym of $R$. podagrica (Fabricius, 1805), he maintained the two species separate in his catalog because he was not able to examine the types. Different authors (e.g. Gerstaecker 1860; Wulp 1898; Aczél 1950) have considered R. saltatoria to be a synonym of $R$. podagrica, but none of them have examined the types.

Merodina Macquart, 1835: 378. Type-species: Dacus podagrica Fabricius (by monotypy).

Gnathoplasma Enderlein, 1912: 99. Type-species: Gnathoplasma infestans Enderlein (by original designation)

Scelidodontia Enderlein, 1913: 553. Type-species: Scelidodontia hendeliana Enderlein (by original designation).

Polphopsis Enderlein, 1927: 107. Type-species: Richardia telescopica Gerstaecker (by original designation).

Zetekomyia Curran, 1934: 281. Type-species: Zetekomyia banski Curran, nomen nudum (by original designation) = Richardia telescopica Gerstaecker.

Diagnosis. Richardia differs from all genera of Richardiinae in the following characters: hind femur distinctly thicker than mid femur; and apical region of vein $\mathrm{R}_{4+5}$ slightly curved to vein $M_{1}$ (Fig. 9). In addition, the genus can be recognized by the following combination of characters: lunula not developed; frons not protruded; ocellar and orbital setae long and similar in length; arista with long pubescence; lateral vertical seta shorter than medial vertical seta; proepimeron ciliated. Thorax with postcoxal bridge generally complete, incomplete in a few species (e.g. Richardia numerifera Enderlein); one postpronotal; one weak proepimeral; one anepisternal; two notopleurals; one presutural supra-alar; one postsutural supraalar; one postalar; one long intra-alar, as long as postalar seta; two dorsocentrals; one apical scutellar and one basal scutellar setae; metathoracic spiracle with strong setae on posterior surface; prosternum and metasternum ciliated; katatergite without setae, with dense pollinosity. Fore femur with or without spines; mid and hind femora with spines on antero and posteroventral surfaces. Wing with crossvein r-m on $4 / 5$ of cell dm (Fig. 9); vein $\mathrm{A}_{1}$ long, reaching wing margin. Abdomen with syntergite $1+2$ long, more than 1.5 times longer than tergite 3 (Fig. 9); sternite 1 absent; sternite 2 reduced; female sternites 4-6 generally with basal apodemes.

\section{Richardia intemperata sp. nov.}

(Figs. 1-10; 16)

Diagnosis. Males of Richardia intemperata differ from all other males of Richardia in the shape of the cuticular projection and the modified spines on the hind femur (Figs. 57). The hind femur has a long and ciliated sub-basal cuticular projection on the ventral surface; basal $1 / 3$ with a slight concavity on ventral and posteroventral surfaces and another cuticular projection with three strong spines on posteroventral surface. Besides, similarly to $R$. pectinata and $R$. tuberculata, the hind tibia of $R$. intemperata has a pointed modification at the apex (Fig. 8).

Description. Holotype male. Measurements (in mm): 6.4 (body length), 5.4 (wing), 3.6 (abdomen). Head (Figs. 3-4): 1.3 times wider than high. Frons 1.4 times higher than wide (at level of anterior ocellus); yellow with two oval dark brown spots above lunula (Fig. 3); frons bright dark brown from ocellar triangle and insertion of orbital setae to vertex (Fig. 3). Ocellar triangle dark brown. Face yellow. Parafacial light brown, covered with dense whitish pollinosity. Scape and pedicel yellow. Postpedicel with dorsal $2 / 3$ brown and ventral $1 / 3$ yellow. Arista broken in the specimen. Clypeus (Fig. 3), prementum and palpus (Fig. 4) light brown. Gena dark brown covered with whitish pollinosity. Postgena light brown. Occiput dark brown. Region between postgena and occiput with semicircular stripe of dense silvery pollinosity. Postocellar seta weak. Genal seta present and postgenal seta absent. Setae on postgenal region weak and whitish. Thorax: General color black (Fig. 1). Scutum with three stripes of silvery pollinosity interspersed with two brown stripes, but not clearly separated. Postpronotal lobe light brown (Fig. 1). Anepisternum entirely black with silvery pollinosty on posterior half. Notopleuron, katatergite, anatergite and posterior half of meron covered with dense silvery pollinosity. Ventral half of katepisternum without long and 

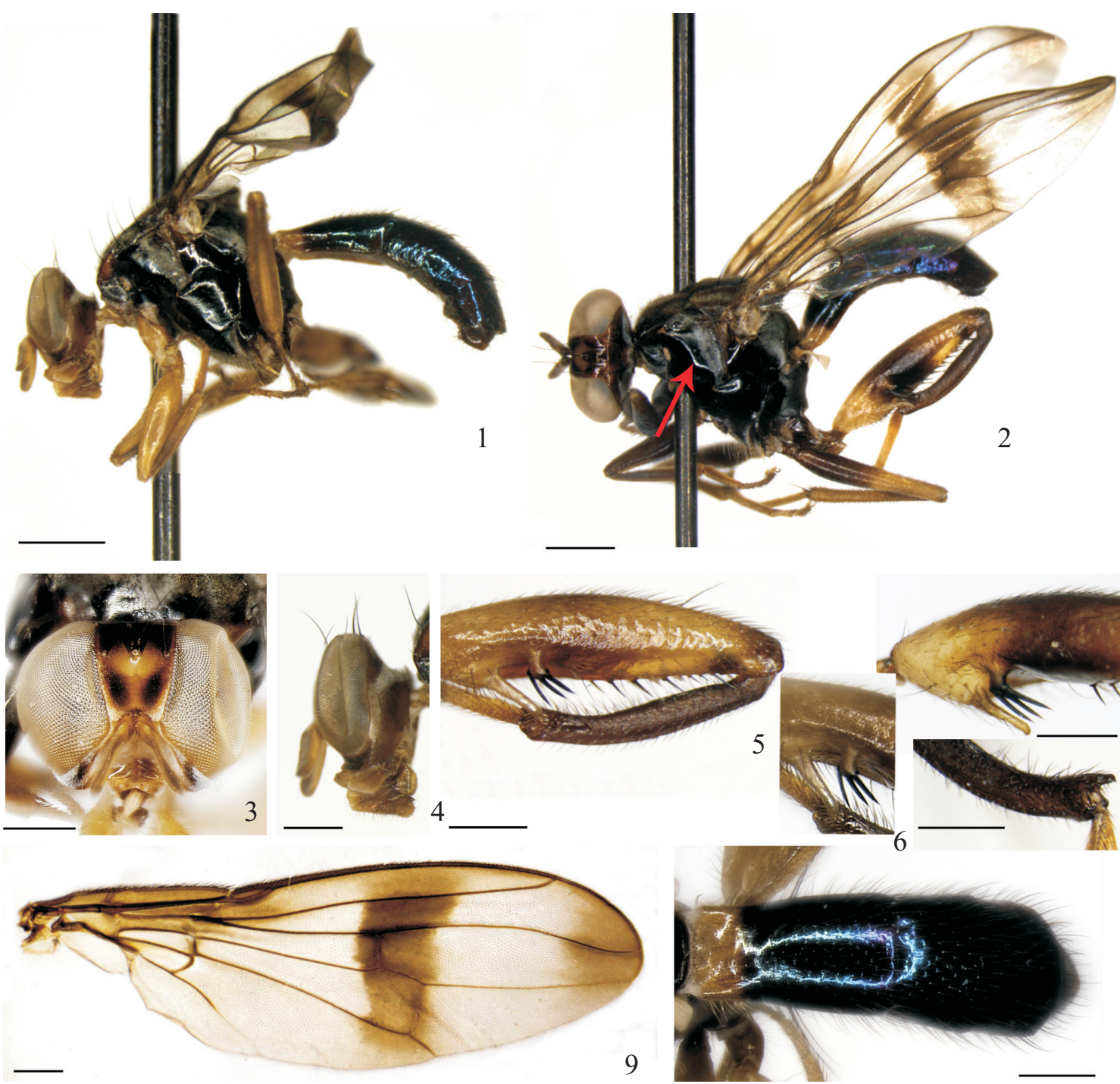

8

Figs. 1-10. Richardia intemperata sp. nov.: 1-2: Habitus, lateral view, male: 1. Holotype; 2. Paratype; 3-4. Head, holotype: 3. Frontal view; 4. Lateral view; 5-8: Hind leg, holotype: 5. Femur and tibia, posterior view; 6. Spines on femur in detail; 7. Tubercle and spines; 8. Tibia, apical portion; 9. Wing, paratype; 10. Abdomen, holotype. Scales: 1-2: $1.0 \mathrm{~mm}$; 3-10: $0.5 \mathrm{~mm}$.

modified setae. Scutellum dark brown with red-brownish pollinosity. Halter whitish. Postcoxal metathoracic bridge completely sclerotized. Legs (Figs. 5-8): Yellow, except fore tarsomeres and mid tibia, light brown; hind tibia dark brown; weak light brown band on mid third of hind femur. Fore femur without spines and without long and sinuous setae. Mid femur with spines on antero and posteroventral surfaces from apical $1 / 3$; posterior surface with a slightly developed seta on apical $1 / 3$. Hind femur with long and ciliated sub-basal finger-like cuticular projection on ventral surface (Figs. 5-7); basal 1/3 with shallow concavity on ventral and posteroventral surfaces and cuticular tubercle bearing three strong spines on posteroventral surface (Figs. 5-7); two rows of spines on antero and posteroventral surfaces from apical half. Hind tibia with pointed process at apex (Fig. 8). Wing (Fig. 9): Light brown with three brown spots: one on basal half of anterior margin of wing, from base to apex of $\mathrm{R}_{1}$; a wide transversal median band, and an apical band slightly lighter in color than the preceding one. Abdomen (Fig. 10): General color black with green bluish metallic shine. Syntergite $1+2$ yellow at base; twice longer than tergite 3 (Fig. 10). Terminalia (Fig. 16): Surstyli similar in length. Lateral surstylus with comma-shaped elongated projection on anterior sub-basal region. Medial surstylus with strong semi-circular projection on anterior basal region, with rounded apex. Prensiseta strong and asymmetrically bifurcated, inserted on lateral preapical margin of medial surstylus. Proctiger slightly sclerotized, rounded, with setae of different sizes and with distinct long pair of setae on ventral surface.

Variation. Paratype (Figs. 2; 9): Frons with two dark brown elongated spots above lunula to insertion of orbital seta. Face dark brown, covered with whitish pollinosity. Pedicel and flagellomere dark brown. Arista brown. Postpronotal lobe dark brown. Fore leg, mid tibia at basal half and band on median part of hind femur dark brown (Fig. 2). 
Comments. One of the paratypes differs distinctly from the holotype in the coloration of the head and legs, a discrepancy we considered to reflect intraspecific variation because, in all characters considered taxonomically important, the two specimens are morphologically very similar, including the male terminalia, and the modified spines and the projection on the hind femur.

Type-material. Holotype male (INPA): "Brasil, AM [Amazonas], Manaus. IReserva Km 41, PDBFF [Projeto Dinâmica Biológica de Fragmentos Florestais/Project Biological Dinamic of Forest Fragments]. ITrilha [trail] R B - Sub-Bosque|02-04.ii.2005|R. Querino col.”. Remarks: Specimen in good condition, except for the left medial vertical and orbital setae, which are broken; the abdomen is detached from tergite 3 , placed in a micro-vial with glycerin, and pinned together with the specimen.

Paratypes: 2 males (INPA): Same data as the holotype|Trilha [trail] J B - Sub-Bosque|16-17.ii.2005lidem; idem, 16-18.iii.2005, idem.

Geographic distribution. Brazil (Amazonas).

Etymology. The specific epithet refers to the extravagant tubercle and spine on the hind femur (from Latin intemperatus = excessive, intemperate).

\section{Richardia parispina sp. nov.}

(Figs. 11-15; 17; 20)

Diagnosis. Similarly to males of Richardia flavipes Schiner (Fig. 19) and $R$. calcarata Hendel (Fig. 18), males of $R$. parispina sp. nov. (Fig. 20) have two modified spines on the hind femur. These spines, however, differ substantially in position and shape among the three species. In males of Richardia parispina sp. nov., the hind femur has a ventrally convex subbasal region, which is wider than the median and apical regions, and the posteroventral surface has two strong sub-median spines inserted closely and oblique to each other (Figs. 14; 20).

Description. Holotype male. Measurements (in mm): 7.0 (body length), 5.8 (wing), 3.7 (abdomen). Head (Figs. 1213): 1.4 times wider than high. Frons 1.4 times higher than wide (at level of anterior ocellus); yellow below and bright brown on region from ocellar triangle and insertion of orbital setae to vertex (Fig. 12). Ocellar triangle dark brown. Face yellow. Parafacial yellow, covered with dense whitish pollinosity. Scape, pedicel and postpedicel yellow. Arista dark brown. Clypeus and prementum yellow. Palpus light brown. Gena yellow, covered with whitish pollinosity. Postgena brown. Occiput dark brown. Region between postgena and occiput with a semicircular stripe of dense silvery pollinosity. Postocellar seta weak. Genal seta present and postgenal seta absent. Setae on postgenal region weak and whitish. Thorax (Fig. 11): General color dark brown. Scutum with three stripes of silvery pollinosity interspersed with two brown stripes, but not clearly separated. Postpronotal lobe dark brown. Posterior half of anepisternum yellow, without pollinosity (Fig. 11). Notopleuron, katatergite, posterior $1 / 3$ of anatergite, posterior half of meron with dense silvery pollinosity. Ventral half of katepisternum covered with very long, curved and yellow setae. Scutellum dark brown with red-brownish pollinosity. Halter and lower calypter whitish. Postcoxal metathoracic bridge com- pletely sclerotized. Legs (Figs. 14; 20): Yellow, except mid and hind coxae, dark brown, and fore and hind tarsi, brown. Fore femur without spines, with yellow, long and sinuous setae on ventral surface. Mid femur with spines on antero and posteroventral surfaces from apical 1/3; posterior surface with strong seta on apical $1 / 3$. Hind femur with strong preapical seta on anteroventral surface inserted a little beyond ventral row of spines; sub-basal region convex ventrally and wider than median and apical regions in lateral view; posteroventral surface with two strong sub-median spines inserted close and oblique to each other (Figs. 14; 20). Hind tibia without apical modification. Wing: Light brown with three brown spots: one on basal half of anterior margin of the wing from base to apex of $\mathrm{R}_{1}$; a wide transversal median and an apical band, slightly lighter than the others. Abdomen (Fig. 15): General color dark brown with green bluish metallic shine. Syntergite $1+2$ yellow at base; 2.5 times longer than tergite 3 (Fig. 15). Terminalia (Fig. 17): Surstyli similar in length. Lateral surstylus with circular and serrated projection on anterior sub-basal region (Fig. 17). Medial surstylus with strong semi-circular projection on anterior basal region; rounded at apex. Prensiseta strong and asymmetrically bifurcated, inserted on lateral preapical margin of medial surstylus. Proctiger slightly sclerotized, semi rounded, with setae of different sizes and with distinct pair of long setae on ventral surface.

Variation. Paratype: Frons with two dark brown spots above lunula and near eye margin. Prementum brown.

Type-material. Holotype male (INPA): "Brasil, AM [Amazonas], Manaus.|Reserva Km 41, PDBFF [Projeto Dinâmica Biológica de Fragmentos Florestais/Project Biological Dinamic of Forest Fragments]. ITrilha [trail] J I Sub-Bosque|30. iii - 1. iv. 2005|R. Querino col.” Remarks: Specimen in good condition, except for right mid and hind legs broken, glued to a card point. Paratype: 1 male (INPA): Brazil, Amazonas, Km 31, Embrapa, 18.ix.1990, L.P. Albuquerque \& J.E. Binda cols., Shannon Trap with fruit bait (cocoa).

Geographic distribution. Brazil (Amazonas).

Etymology. The specific epithet refers to the two spines on the hind femur (from Latin paris = pair; spina = spine, thorn).

\section{Richardia calcarata Hendel}

(Fig. 18)

Richardia calcarata Hendel, 1912: 8. Holotype male, BMNH (examined through photographs). Type-locality: Brazil, Amazonas, Santarém.

Distribution. Guyana (new record), Brazil: Amazonas.

Examined material. Holotype male (BMNH): "Santarém|R.[river] Amazonas $\mid$ Brasil|H.W. Bates"; 1 male and 1 female (BMNH): Guyana, Demerara, 20.ix.1931, bred from pineapple, F.A. Squire col.

\section{Richardia pectinata Hendel}

(Fig. 21)

Richardia pectinata Hendel, 1912: 7. Holotype male, BMNH (examined through photographs). Type-locality: Brazil, Pará, Amazonas River, "West of Parana River".

Distribution. Brazil: Amazonas, Pará. 


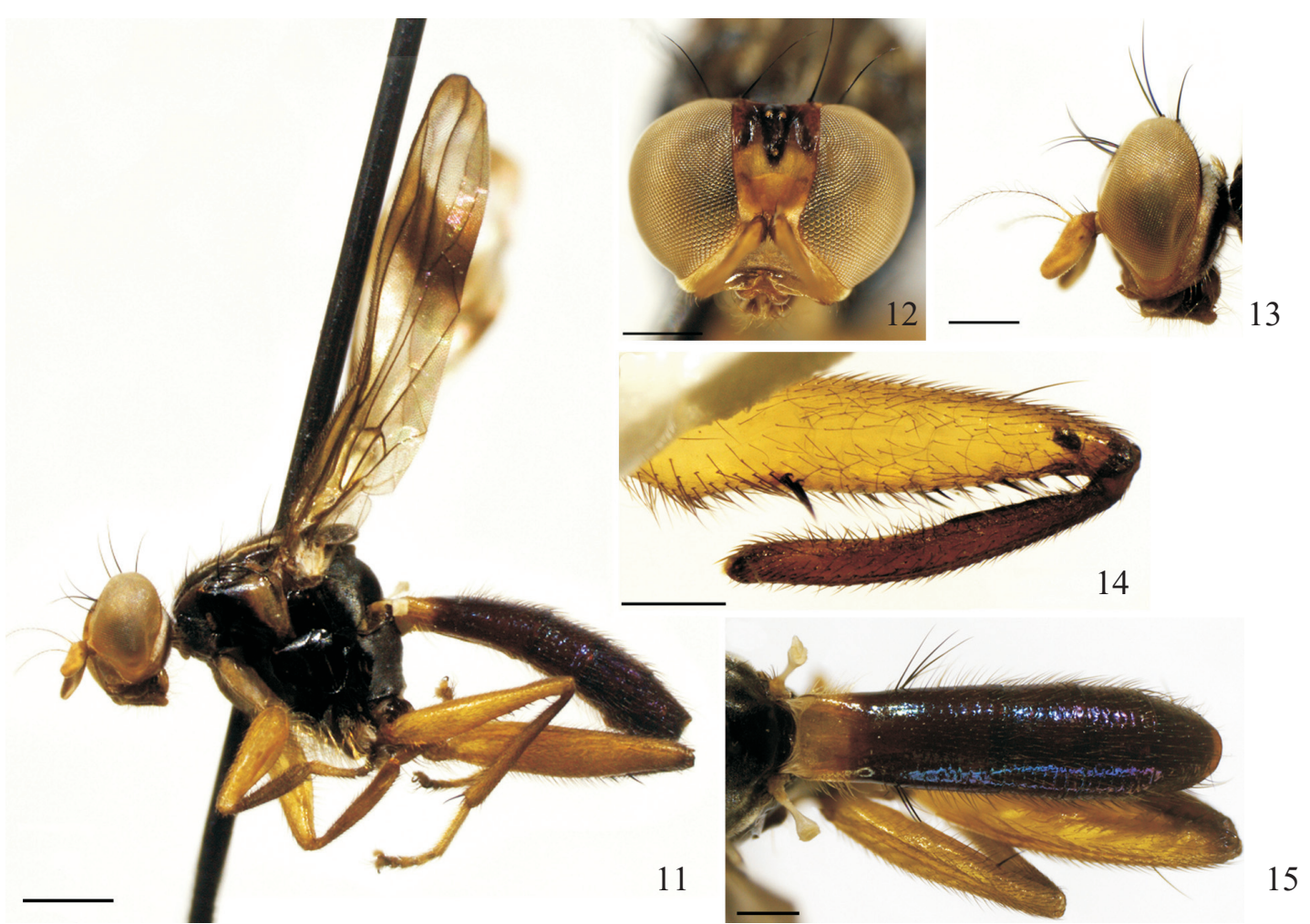

Figs. 11-15. Richardia parispina sp. nov., holotype, male: 11. Habitus, lateral view; 12-13: Head: 12. Frontal view; 13. Lateral view; 14. Hind femur, posterior view; 15. Abdomen, dorsal view. Scales: 11: $1.0 \mathrm{~mm}$; 12-15: $0.5 \mathrm{~mm}$.

Additional examined material (INPA). Brazil, Amazonas, Manaus, Reserva Km 41, PDBFF. [Projeto Dinâmica Biológica de Fragmentos Florestais/Project Biological Dinamic of Forest Fragments], trilha CI-SubBosque, 05-06.ix.2004, R. Querino col. (1 male); idem, trilha RB-Dossel, 22.xii.-07.i.2005, idem (1 male); idem, trilha AB B-Sub-Bosque, 1617.ii.2005, idem (1 male); idem, trilha JB-Sub-Bosque, 02-04. iii.2005, idem (1 male).

\section{Richardia podagrica (Fabricius)}

(Fig. 22)

Richardia podagrica (Fabricius, 1805): 272 (Dacus). Holotype, sex unknown, ZMUC (Meier et al., 2005; not examined). Type-locality: "South America".

Distribution. Mexico, Costa Rica, Guiana, Trinidad, Brazil (Amazonas), Peru, Bolivia.

Examined material (INPA). Brazil, Amazonas, Manaus, Reserva Km 41, PDBFF [Projeto Dinâmica Biológica de Fragmentos Florestais/Project Biological Dinamic of Forest Fragments], 09-10.vi.2004, Suspended Trap, Sub-Bosque, R. Querino, S. Costa, A. Nazareno, L. Queiroz, M. Feitosa, O. Pereira cols. (1 male, 1 female); idem, trilha ABI-Sub-Bosque, 0506.vii.2004, R. Querino col. (1 male), idem, 05-06.ix.2004, idem (1 female); idem, trilha RI-Sub-Bosque, 10-12.xi.2004, idem (1 male); idem, trilha ABB-Dossel, 29-30.ix.2004, idem (1 female); idem, trilha JB-SubBosque, 27-28.x.2004, idem (1 male); idem, trilha RI-Sub-Bosque, $27-$ 28.x.2004, idem (1 male); idem, trilha JI-Dossel, 22.xii-07.i.2005, idem (1 male); idem, idem, Sub-Bosque, 22.xii-07.i.2005, idem (1 male); idem, trilha CI-Sub-Bosque, 19-21.i.2005, idem (1 female); idem, trilha CB-SubBosque, idem (1 female); idem, trilha ABB-Sub-Bosque, 02-04.ii.2005, idem (1 female); idem, trilha EEB-Sub-Bosque, 16-17.ii.2005, idem (1 female); idem, trilha EEI-Sub-Bosque, idem (1 female); idem, trilha JI-
Sub-Bosque, 02-04.iii.2005, idem (1 female); idem, trilha JB-Sub-Bosque, 30.iii.-01.iv.2005, idem (1 male).

\section{Richardia telescopica Gerstaecker}

Richardia telescopica Gerstaecker, 1860: 167 (pl. 2, 2a). Holotype male, ZMHB (examined). Type-locality: Amazon River, Brazil.

Distribution. Nicaragua, Costa Rica, Panama, Brazil.

Examined material. Holotype male (ZMHB): "Amazon. Warscew [Warscewicz] [hand written]" "2321" [museum catalog number] "Type" "telescopica|Gerst.* [hand written]".

\section{Key to males of Richardia from the Brazilian Amazon}

1. Head expanded laterally, three or more times wider than high. General color of thorax and abdomen yellow to pale brown. Wing without transversal spots

Richardia telescopica Gerstaecker

1'. Head not expanded laterally, slightly wider than high. General color of thorax and abdomen dark brown to black. Wing with transversal spots (e.g. Fig. 9).

2. Posterior half of anepisternum yellow, without pollinosity (e.g. Fig. 11)

2'. Posterior half of anepisternum black, covered with dense silvery pollinosity (e.g. Figs. 1-2) ................................ 4

3 . Hind femur with two spines on sub-median region on posterior surface, in addition to the row of simple spines on antero and posteroventral surfaces; sub-basal region on 
ventral surface thicker than median and apical regions (Figs. 14; 20) Richardia parispina sp. nov.

3 ' Hind femur without modified spines, only with a row of simple spines on antero and posteroventral surfaces; subbasal region on ventral surface similar to the median and apical regions (Fig. 22)

Richardia podagrica Robineau-Desvoidy

4. Hind femur with a sub-basal cuticular projection on ventral surface (Figs. 5; 21). Hind tibia with a distinct modification at apex (Figs. 8; 21) ....
4'. Hind femur without sub-basal cuticular projection on ventral surface (Fig. 18). Hind tibia without modification at apex (Fig. 18) Richardia calcarata Hendel

5. Hind femur with short and bare cuticular projection; posteroventral surface with sub-median row of 6-8 spines (Fig. 21) Richardia pectinata Hendel

5'. Hind femur with long and ciliated cuticular projection; posteroventral surface with protruded region with three long and strong setae (Figs. 5-7)

Richardia intemperata sp. nov.
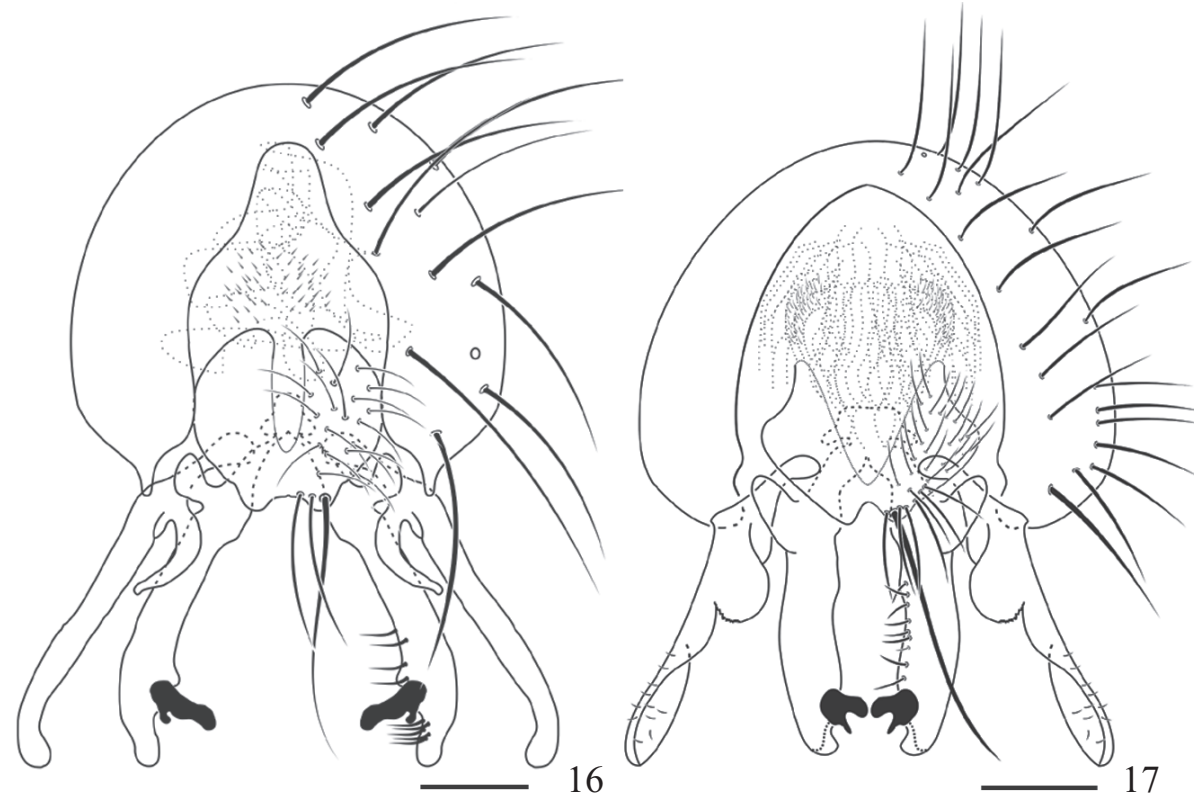

Figs. 16-17: Drawings of the male genitalia (epandrium, surstyli and proctiger), dorsal view: 16. Richardia intemperata sp. nov.; 17. Richardia parispina sp. nov. Scales: $0.1 \mathrm{~mm}$.
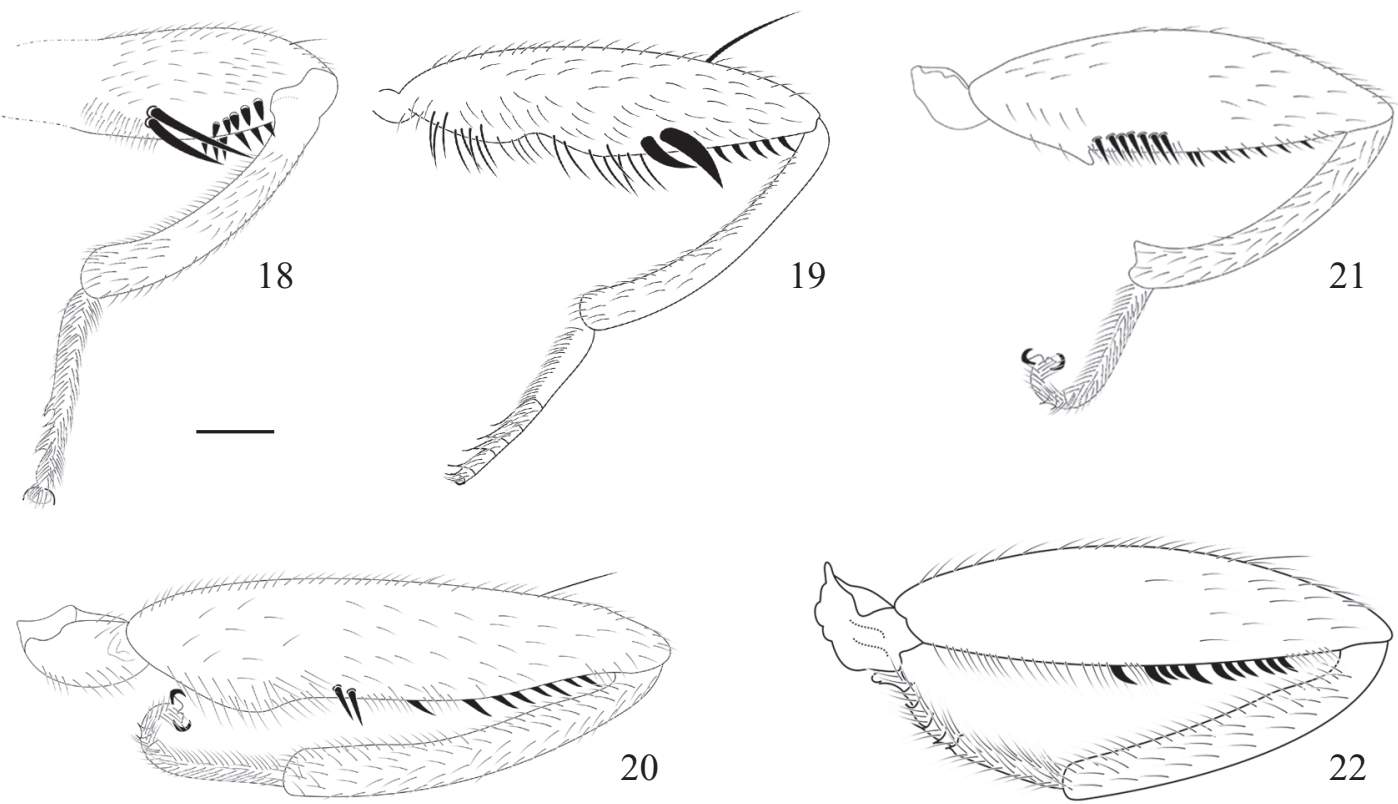

Figs. 18-22: Drawings of the hind leg: 18. Richardia calcarata Hendel; 19. R. flavipes Schiner (modified from Hendel 1911b); 20. R. parispina sp. nov. 21. R. pectinata Hendel; 22. R. podagrica Robineau-Desvoidy. Scale: $0.6 \mathrm{~mm}$. 


\section{ACKNOWLEDGMENTS}

Our thanks to Dr. K. Goodger (BMNH) for loaning specimens (Richardia calcarata) and for sending photographs of the type-material of Richardia pectinata and to Dr. Joachim Ziegler (ZMHB) for allowing us to study the type-material of $R$. telescopica. The senior and second authors are grateful to the Conselho Nacional de Desenvolvimento Cientifico e Tecnológico (CNPq) (process numbers-129723/2010-0, 142325/2008-2, respectively), to the Coordenação de Aperfeiçoamento de Pessoal de Nível Superior (CAPES) and to the Fundação de Amparo à Pesquisa do Estado do Amazonas (FAPEAM) for the scholarship provided. We also thank CNPq for supporting the project "Sistemática de Periscelididae (Diptera, Schizophora) da região Neotropical, com ênfase nas espécies amazônicas" (process number 574999/2008-6, CNPq). Automontage equipment was available to us through the project "Amazonas: Diversidade de insetos ao longo de suas fronteiras" (PRONEX/FAPEAM Proc. 1437/2007/NTO318/07) headed by Dr. José Albertino Rafael. We also thank Dr. Ranyse Querino for collecting part of the material studied.

\section{REFERENCES}

Aczél, M. 1950. Catalogo de la sufamilia americana "Richardiinae" (Dipt. Acalypt. Otitidae). Acta Zoologica Lilloana 9: 5-47.

Carvalho, C.J.B., Wolff, M. \& Wendt, L.D. 2011. A new stalk-eyed species of Batrachophthalmum Hendel (Diptera, Richardiidae) from Colombia. Zootaxa 2932: 41-46.

Cumming, J.M. \& Wood, D.M. 2009. Morphology and terminology, p. 950. In: Brown, B.V., Borkent, A., Cumming, J.M., Wood, D.M., Woodley, N.E. \& Zumbado, M.A. (eds.). Manual of Central American Diptera. v. 1, Ottawa, NRC Research Press, 714 p.

Curran, C. H. 1934. The families and genera of North American Diptera. $1^{\text {st }}$ ed., New York, Woodhaven, 515 p.

Enderlein, G. 1912. Die Richardiiden des Stettiner Museums. Sitzungsberichte der Gesellschaft Naturforschender Freunde zu Berlin 1912: 99-113.

Enderlein, G. 1913. Dipterologische Studien. VI. Neue Beitrage zur Kenntnis der Richardiiden. Zoologiscker Anzeiger 42: 553-555.

Enderlein, G. 1927. Dipterologische Studien. XIX. Stettiner Entomologische Zeitung 88: 102-109.
Fabricius, J.C. 1805. Systema antliatorum secundum ordines, genera, species. Brunsvigae, Reichard, $373 \mathrm{p}$.

Gerstaecker, A. 1860. Beschreibung einiger ausgezeichneten neuen Dipteren aus der Familie Muscariae. Stettiner Entomologische Zeitung 21: 163-202.

Hancock, E.G. 2010. Richardiidae (Richardiid flies), p. 871-879. In: Brown, B.V., Borkent, A., Cumming, J.M., Wood, D.M., Woodley, N.E. \& Zumbado, M.A. (Eds.), Manual of Central America Diptera. v.2, Ottawa, NRC Research Press, 728 p.

Hendel, F. 1911a. Die Arten der Dipteren-subfamilie Richardiinae. Deutsche Entomologische Zeitschrift 1911: 181-212; 239-270; 367-396.

Hendel, F. 1911b. Diptera. Fam. Muscaridae, Subfam. Richardiinae. Genera Insectorum 113: 1-56.

Hendel, F. 1912. Neue Muscidae acalyptratae. Wiener Entomologische Zeitung 31: 1-20.

Hennig, W. 1938. Beiträge zur Kenntnis der Richardiiden (Dipt.). Revista de Entomologia 8: 111-122.

Macquart, J. 1835. Histoire naturelle des insectes. Diptères. Tome 2. Paris, Librairie Encyclopédique de Roret, 703 p.

Meier, R., Buch, W., Buhl, P.N., Klass, K.D., Michelsen, V.\& Petersen, J.F.T. 2005. Collection inventory of the Diptera collection of the Zoological Museum, University of Copenhagen (ZMUC). Available at: http:// www.zmuc.dk/EntoWeb/collections-databaser/Diptera/dipterasites.htm (accessed 5 February 2013).

Ministério da Integração Nacional, Ministério do Meio Ambiente. 2004. Plano Amazônia Sustentável: Diagnóstico e Estratégia. v.2. Brasília, 113 p.

Perez-Gelabert, D.E. \& Thompson, F.C. 2006. A new genus and species of Richardiidae (Diptera) from Hispaniola. Zootaxa 1259: 25-31.

Robineau-Desvoidy, J.B. 1830. Essai sur les myodaires. Mémoires Présentés par divers Savants a l'Académie Royale des Sciences de l'Institut de France 2: 1-813.

Steyskal, G.C. 1968. Family Richardiidae, p. 1-20. In: Vanzolini, E. P. \& Papavero, N. (eds.). A catalogue of the Diptera of the Americas South of the United States. São Paulo, Departamento de Zoologia, Secretaria da Agricultura do Estado de São Paulo.

Steyskal, G.C. 1987. Family Richardiidae, p. 833-837. In: McAlpine, J.F. (ed.). Manual of Nearctic Diptera. v. 2, Research Branch, Agriculture Canada Monograph 2, 675-1332 p.

Wendt, L.D. \& Ale-Rocha, R. 2012. Redescription of the genus Coniceps Loew, 1873 (Diptera, Richardiidae). Zootaxa 3238: 49-56.

White, I.M., Headrick, D.H. Norrbom, A.L. \& Carrol, L.E. 1999. Glossary, p. 881-924. In: Aluja, M. \& Norrbom, A.L. (eds.). Fruit flies (Tephritidae): Phylogeny and evolution of behavior. Washington, CRC Press Boca Raton, 994 p.

Wulp, F.M. van der. 1898. Group Ortalinae, p. 387-400. In: Godman, F.D. \& Salvin, O. (eds.). Biologia Centrali-Americana, Diptera, v. 2. London, R. H. Porter, 488 p. 